\title{
First International Research Conference on Weaponology in Kyiv, Ukraine: A ground-breaking start
}

\author{
Denis TOICHKIN ${ }^{* 1} \&$ Manouchehr Moshtagh KHORASANI ${ }^{2}$ \\ ${ }^{1}$ Institute of History of Ukraine (Ukraine) \\ ${ }^{2}$ Independent researcher (Germany)
}

Recepción: 06/06/2014; Aceptación: 21/06/2014; Publicación: 24/06/2014.

\begin{abstract}
The present report provides a short description of a conference entitled "First International Research Conference on Weaponology in Kyiv, Ukraine". It was the first scientific conference dedicated to the study of historical arms and armor in Ukraine. A number of international experts in the field of historical arms and armor were invited to the conference. Each researcher had been asked to provide a short and a long article on a specific research subject. The short articles were published as a short essay in a peer-review booklet that was handed out before the start of the conference. The long articles will be published together as a large book in future.
\end{abstract}

Keywords: Conference on historical weapons; historical firearms; martial arts; scientific research; scientific meetings; arms; armor.

\section{First International Research Conference on Weaponology in Kyiv, Ukraine: Un comienzo innovador}

\section{Resumen}

El presente informe describe brevemente la conferencia titulada "First International Research Conference on Weaponology in Kyiv, Ukraine" [Primera Conferencia de Investigación sobre Armas en Kiev, Ucrania]. Fue la primera conferencia científica en Ucrania dedicada al estudio de las armas y de las armaduras históricas. Diversos expertos internacionales en el campo de las armas y armaduras históricas fueron invitados a la conferencia. A cada uno de ellos se le solicitó que proporcionase un artículo corto y un artículo extenso sobre un tema de investigación específico. Los artículos cortos fueron publicados como ensayos en un librillo revisado por pares que fue distribuido antes del comienzo de la conferencia. Los artículos extensos serán publicados como libro colectivo en el futuro.

Palabras clave: Conferencia sobre armas históricas; armas de fuego históricas; artes marciales; investigación científica; reuniones científicas; armas; armaduras.

\section{First International Research Conference on Weaponology in Kyiv, Ukraine: Um início inovador}

\section{Resumo}

0 presente resumo descreve brevemente a conferência intitulada "First International Research Conference on Weaponology in Kyiv, Ukraine" [Primeira Conferência de Investigação Internacional em Armamento, em Kyiv, Ucrânia]. Foi a primeira conferência científica na Ucrânia dedicada ao estudo de armas e de armaduras históricas. Diversos especialistas internacionais, no domínio das armas e armaduras históricas, foram convidados a participar no evento. Foi solicitado a cada um deles que escrevesse um artigo curto e um artigo extenso sobre um tema de investigação específico. Os artigos curtos foram publicados como ensaios num livro revisto por pares (referees) e foi distribuído antes do início da conferência. Os artigos extensos serão publicados num livro coletivo futuramente.

Palavras-chave: Conferência sobre armas históricas; armas históricas de fogo; artes marciais; investigação científica; reuniões científicas; armas; armaduras.

*Email: denisvt@yandex.ua. Address:. Institute of History of Ukraine. 4 Mykhailo Hrushevsky str., Kyiv 01001 (Ukraine). 


\section{1.- Introduction}

An international weaponology conference was held from February 16th to 19th in Kyiv, Ukraine. The conference was supported and organized by National Academy of Sciences of Ukraine, National Military History Museum of Ukraine, Institute of History of Ukraine and Ministry of Defence of Ukraine. The organizers of the conference were Dr. Denis Toichkin (Institute of History of Ukraine), Mr. Vladislav Taranets (Head of the National Museum of Military History of Ukraine), Mr. Valeriy Smolij (Head of the Institute of History of Ukraine), Ms. Natalia Kursanina (curator of the collections of the National Military History Museum of Ukraine) and Mr. Hennadii Gutgartz (administrator). One should note that such an event took place in Ukraine for the first time. Nevertheless, the conference had an international nature with many researchers from different countries discussing the general development of Ukrainian weaponology science. Although the development of archaeological research and the history of weapon collecting in Ukraine have a long and venerable history, weaponology as an auxiliary historical discipline in Ukraine is a relatively new science. Neverthless, a community of professional researchers, engaged in studying the history of historical arms and armor, established a center of research to organize such an event in Ukraine. To present the latest scientific trends, such as archaeometallurgy and military anthropology, it was important to invite international researchers who could present on these issues during the conference.

The speakers were: a) Dr. Anna Feuerbach (Hofstra University; Nassau Community College, NY, USA), b) Dr. Vladimir Hutsul (Uzhhorod National University, Uzhhorod,Ukraine), c) Dr. Helena Pohodyascha (National Academy of Culture and Arts, Kiyv, Ukraine), d) Dr. Michael Gorelik (Institute of Oriental Studies of the Russian Academy of Sciences, Academy of Arts of the Republic of Kazakhastan, Moscow, The Russian Federation), e) Dr. Sergey Pivovarov (National Kyiv-Pechersk Historical and Cultural Preserve Kiyv, Ukraine), f) Mr. Vitaly Kalinichenko (Yuriy Fedkovych Chernivtsi National University, Chernivtsi, Ukraine), g) Dr. Vladimir Prokopenko (Institute of Bioorganic Chemistry and Petrochemistry of National Academy of Sciences of Ukraine, Kiyv, Ukraine), h) Dr. Nicholas Plavinsky (Belarussian State Agrarian Technical University, Minsk, Republic of Belarus), i) Dr. Alexander Strelchenko (Moscow Psychological and Social University, Moscow, the Russian Federation), j) Mr. Bohdan Grinchishin (Lviv Polytechnic National University, Lviv, Ukraine), k) Dr. Helena Popelnytska (National Museum of History of Ukraine, Kiyv, Ukraine), l) Mr. Dmitry Badaev (Kharkiv State Historical Museum, Kharkiv, Ukraine), m) Mr. Alexander Berezkin (Ukrainian Institute of Military History, Kyiv, Ukraine), n) Mr. Artem Laevsky (Chernigov Historical Nuseum, Chernigov, Ukraine), o) Mr. Eugene Sivachenko (Museum of Private Collections, Feldman Family Museum Kharkiv, Ukraine), p) Mr. Vitaly Shlaifer (Museum of History of Weapon, Zaporizhzhya, Ukraine), q) Mr. Roman Kosarev (Researcher and expert, Zaporizhzhya, Ukraine), r) Mr. Valery Nefiodov (Khortytsa National Reserve, Zaporizhzhya, Ukraine), s) Dr. Manouchehr Moshtagh Khorasani (M. Khorasani Consulting, Frankfurt a. M. Germany), t) Dr. Tomasz Ciesielski (Opole University, Institute of History, Opole, Poland), u) Dr. Oleg Malchenko (M. S. Hrushevsky Institute of Ukrainian Archeography and Source Studies, Kiyv, Ukraine), v) Dr. Sergey Zelenko (Taras Shevchenko National Uuniversity of Kyiv, Kiyv, Ukraine), w) Ms. Katharine Valentirova (Taras Shevchenko National University of Kyiv, Kiyv Ukraine), x) Mr. Victor Kobets (Centre of Underwater Archaeology of Kiev National University), and y) Ms. Iryna Forostyan (Metropolitan Museum of Art, Security Department, the Fund Research of Ancient Civilization; Museum of Trypillya, NY, USA).

The goal of the conference was to present new sources on the history of arms and armor, the development of international scientific cooperation in the studies of military history, the analysis of historical arms and armor kept in museums and private collections in Ukraine and across the world and a discussion of the problems associated with the preservation, restoration and exhibition of historical arms and armor. Each speech lasted 20 minutes during the conference. There were some questions after each speech. The whole conference was recoreded and these questions can be retrieved if needed. In the booklet and program of the conference (see References section), every participant could find the names and a short introduction to each speech. The speeches were held in three languages: Russian, English and Ukranian. Tomasz Ciesielski held his speech in Polish which was interpreted simultaneously. Every international participant who could not speak Ukranian or Russian had a personal interpreter. 


\section{2.- The Conference}

Dr. Anna Feuerbach, a well-known specialist in the field of history of technology production and decoration of antique weapon gave a speech titled "Koftgari and Other Related Methods of Decoration on Weapons". Her presentation was devoted to the study of different techniques used to decorate Indian, Middle Eastern and Central Asian antique weapons, and how this information could be used to further weapons research and distinguish between different weapons. When describing the application of gold, and occasionally other metals, to decorate a blade, the terms "damascening", "koftgari" or "inlay" are often used. Anna Feuerbach precisely identifies the main traditional methods of applying decoration to blades including: notching, amalgamation, and inlaying. She especially concentrated on "koftgari" techniques and its variants. She suggested creating a public electronic database where all methods of blade decorating could be documented.

Among the most recent Ukrainian studies devoted to the history of military technologies, one should consider the speech of Dr. Vladimir Hutsul titled "Weapons and Tactics of Hussar Cavalry in the Visual Sources of the First Third of the 16th Century". Vladimir Hutsul used a wide range of iconographic and written sources to investigate the depiction and description of light Balkan cavalry as formation of European troops. The author has also studied their arms and armor and related warfare. His research is also accompanied by material sources. Vladimir Hutsul concluded that a comprehensive study of sources would raise the significance of Renaissance pictorial battle arts as historical sources. Further, he stressed that the development of the warfare of the Polish-Lithuanian Commonwealth, including Polish and Lithuanian Rus in the first half of the 16th century was fully integrated into the pan-European trend and opposed the conceptual separation of the military history of Western Europe from the Central and Eastern European ones, such as those of Poland, Lithuania and Russia.

The speech of Dr. Helena Pohodyascha titled "Pictures of Arms and Symbols of Power in the Cossack Portraits of the 17th and the First Half of the 19th Centuries" was closely related to the art history. She studied the images of cold steel on the portraits of Cossack nobles from museums in Ukraine, explaining different opinions regarding their authenticity, as well as the potential of portraits as a historical source. The development of weaponology studies provides solutions to a wide range of tasks: it enables a proper attribution of a huge number of museum artifacts related to arms and armor, the development and testing of research methods and a deep integration with closely related historical sciences, especially archaeology. Therefore, most reports at the conference were devoted to the archaeological problems.

The report of Dr. Michael Gorelik dealt with a very topical theme "The Burial of the Golden Horde Circassian warrior of 13th -15 th centuries in Porosye". Gorelik analyzed an excavated set of antique arms and armor from burial number 69 Yablonovsky near the ancient city of Jurev (now Belaya Tserkov). The analysis of weapons and household items from the burial allowed him to conclude that in the grave there was a buried Circassian warrior of the Golden Horde. The author admitted that the burial belonged to one of the Circassian warriors who had been resettled by the Golden Horde administration to a strategically important area. The author suggested that the Circassians played a prominent role in the military system of the Golden Horde. A large presence of Circassian troops in the Dnieper Basin contributed to the fact that the local Slavic population not only took over the ethnicity of those immigrants, but also reacted favorably to the title "Cherkasy ", which they took over from their eastern neighbors.

The report of Dr. Sergey Pivovarov and Mr. Vitaly Kalinichenko was titled "Items of Arms Ranged from Chornivka Hillfort of the First Half of 13th Century (Archeological Research of 2012)" and devoted to the analysis of the arrowheads found in the Chornivsky settlement, their typology and classification. The identification of these materials yields important data on military and political history of Bukovina region and weaponology in general.

The report of Dr. Vladimir Prokopenko titled "Saber Belt Hanger with a Hook-Clasp. Eastern Europe, Ottoman Empire 16th to Early 18th Century" was dedicated to this little-studied topic in the history of arms and armor. The author reviewed 21 samples of sabers with saber-belt sets, studied metal parts of devices, and proposed approaches to the classification of certain items and types of hanger. 
Interesting materials devoted to the study of medieval swords from the western regions of Rus were revealed by Dr. Nicholaj Plavinsky and Dr. Alexander Strelchenko. The question of the place of manufacture of armaments that were found in the Old Russian archaeological sites is one of the traditional research questions in archaeological and arms and armor studies research. However, it continues to be relevant even today. This is due to the importance and apparent complexity of the issue. In the report titled "Weapons of Local Production and Imported Weapons in the Complex Weapons of the Western Lands of Rus in the 11th -13th centuries: Principles and Criteria of Selection", Dr. Nicholaj Plavinsky examined the criteria of selection of imported weapons in an assortment of weapons using the example of the western lands of Ancient Rus. This term refers to the territory of present day Belarus with the exception of the Nioman region populated by Balts. He stressed that any conclusion of the possibility of the local production of artifacts can only be made after a thorough study of the full set of discovered armaments using traditional methods of archaeological research, such as typological analysis, mapping and statistical analysis. In his report "On a Group of Swords from 14th -15th Centuries from South-Western and Western Rus", Dr. Alexander Strelchenko analyzed the several samples of swords from Museum of Regional Studies of Rivne city and Lviv History Museum. He compared their morphology and marks with the known samples from Western European museums. Through a comparative analysis the author dated swords from the second half of the 14th and the first half of 15th centuries respectively. A. Strelchenko also suggested the existence of a long tradition of local production of sword hilts.

In his report, "Finds of Medieval Swords as an Important Source for the Study of Military Affairs in the Galicia-Volyn State", Mr. Bohdan Grinchishin examined the question of studying swords as a source of shedding light on the history of military affairs. He analyzed swords that had been found in the study area based on the typology of E. Oakeshott and compared them with similar models which had been identified in Western Europe. He pointed out the features of the study of archaeological materials: problems of dating, conservation, and determining the location of the artifact in the warrior's weapon system. He emphasized the need for an integrated investigation of the weapons complex.

A collection of nine medieval swords were examined by Dr. Helena Popelnytska and presented in her report "Swords of the Second Half of 13th -15th centuries from the Collection of the National Museum of History of Ukraine". These swords had been accidentally found in the first half of the 20th century in different regions of Ukraine. She described five of those swords as socalled "Gothic" swords, dated from the second half of 14th-15th centuries. Further she suggested that four swords from the second half of 13th and the first half of the 14th centuries as "Roman" swords - the popular chivalrous weapon of the High Middle Ages. She analysed all of them in detail and paid attention to the history of their acquisition in each respective museum. She concluded that the study of these exhibits was important in the context of understanding history of medieval warfare in Ukraine, which at that time was in the field of cultural and economic interests of the two European countries - Grand Duchy of Lithuania and the Kingdom of Poland.

The next report of Dr. Helena Popelnytska titled "Sword of the First Third of the 19th century of a Russian Statesman Alexander Balashov in the Collection of the National Museum of History of Ukraine" dealt with the study of museum objects from the collection of the National museum of history of Ukraine. The sample in question was the Russian Pattern 1798 Infantry sword. She analysed the toponymic inscriptions on the blade with respect to the outstanding events in the biography of Alexander Balashov. She attempted to identify the inscription "Svalling" engraved on the forte of the blade, connecting it with one of the representatives of Svallings - the royal armourers from Sweden. The sword of Alexander Balashov is of high interest not only as a crafted masterpiece, but also as a historical relic. Through the fate of one man, one can reflect the era of Alexander I, the War of the Russian Empire with Napoleonic France, where Alexander Balashov participated as an officer and as a diplomat.

The next talk dealt with the studies of of the 20th century museum samples conducted by Mr. Dmitry Badaev "Panzer Мк-V - the Monument in Kharkiv". It is dedicated to one of the most prominent monuments in Kharkov - British First World War tank Mk-V Composite, now displayed in the Constitution Square, downtown. The first tank that later turned to a monument arrived to Kharkiv from the city of Novorossiysk in 1920 as part of a large group of captured British tanks. 
The Kharkov railway workshops were involved in repairing it, but failed to renovate several engines. In 1938, the monument tank was replaced with another one.

The report of Mr. Alexander Berezkin titled "Experience of Restoration of the Iron Sword Hilt (10th Century?)" dealt with important topics of restoration and conservation of ancient weapons. He consistently reviewed all phases of the restoration process of a medieval sword. Alexander Berezkin showed how the process of cleaning revealed signs which could be helpful in dating and attribution of a sword. In the next presentation titled "Cold Steel in the Collection of the Chernigov Historical Museum", Mr. Artem Laevsky examined the history and structure of this unique collection. He referred to the history of research exhibitions and also the published catalogues. Further, he paid attention to the composition of the collection and descriptions of exhibitions that had still not been introduced into the scientific circulation.

A number of important reports of the conference were prepared by the largest private museums and collectors of antique arms and armor. One of them was Feldman Family Museum. Mr. Eugene Sivachenko gave a speech titled "The Use of Jade in Weapons' Art of India during the Mughal era: Historical, Technical and Artistic Aspects (Sample Exhibitions in the Feldman Family Museum)". He stated that the widespread use of jade as jewelry material in the manufacture of arms was one of the characteristics of Indian arts and crafts of the Mughal era (1526-1858). The author counted about 40 objects in the collection with hilts which had been made fully or partially made of jade. Mr. Sivachenko also paid attention to the history of the art of jade crafting in India, noting that the Mughals brought to India not only the art of jade, but the mineral itself. he also analyzed the methods of production, assembling and artistic features of jade hilts of bladed weapons, highlighting several basic types according to their morphological characteristics.

Mr. Vitaly Shlaifer presented a rare topic titled "Scythes in the Weapon History Museum". The author analyzed a representative collection of medieval military scythes, examining the history of the development of these weapons and their application in Europe. The speaker paid attention to the methods for adjusting peasant working scythes for combat application and also identified their main morphological types. These reports confirm the great scientific work carried out within the walls of private museums and high scientific level of research teams in these institutions. It's also testified by a significant number of scientific publications, new journals which are devoted to the analysis of problems of research on antique arms.

One of the newest publications which was presented at the Conference was the book of Mr. Roman Kosarev and Mr. Valery Nefiodov titled "Cossack weapons of 15th-18th centuries". This work contained a study of many archaeological finds from the territory of Ukraine and neighboring countries. The material is divided into three groups according to chronological order: 15th-16th centuries, 17th century and 18th century.

A group of reports was devoted to the study of firearms. One of them was dedicated to the study of handguns of the 16th century conducted by Mr. Valery Nefiodov titled "Handguns on the Territory of Ukraine 16th-18th centuries". The report of the well-known researcher of Iranian arms and armor Dr. Manouchehr Moshtagh Khorasani was named "Persian manuscripts on cannon making, different types of ordnances (cannons, howitzers and mortars), rockets and fireworks". The goal of his speech was to give a short overview of some Persian manuscripts on casting bronze cannons, the usage of rockets and different types of ordnance such as cannons, mortars and howitzers. Additionally, some manuscripts on shooting rockets that did not require a bombarding frame was also discussed. He also introduced a manuscript on making and shooting fireworks.

In his presentation, Dr. Tomasz Ciesielski titled "The Artillery Weapon in the Polish and Lithuanian Army in the Years 1717-1789" stated that in 1718 the Polish artillery had about 300 cannons and mortars, which had been predominantly manufactured in the 17 th century. The Lithuanian army had only 10 cannons. From 1718 to 1763, Poland and Lithuania produced about 30 additional cannons. But from 1767 to 1789, two Polish arsenals manufatcured about 243-246 cannons and mortars. In 1789 the Polish artillery had 321 cannons. Thus more than half of Polish artillery cannons were produced in the second half of the 18th century. Dr. Oleg Malchenko (M. Hrushevsky Institute of Ukrainian Archeography and Source Studies, Kyiv, Ukraine) gave a presentation titled "Dutch forged cannon of 15th century from Tavrida Central Museum". He 
analyzed the history of one sample from the central museum of Simferopol city (Crimea, Ukraine). He described the typologyof this type of cannon. He examined several fundamental characteristics based on analogies with similar examples from European museums. He paid attention to the only decorative element - a reinforcing ring, so called "sugarstick". The analysis of the markings on the barrel allowed him to determine the origins of the marking which corresponded to the traditional signs of the Netherlands lower states workshops. He described the cannon as a model "veuglair", which had been manufactured in 1470-1480. He also emphasized the importance of underwater archaeology in the study of medieval artillery.

Three more reports dealt with underwater archaeology topics. This was no surprise because in the last decade more and more researchers have been dealing with the topic. For example, the excavation of a 13th-century shipwreck near Sudak, in Crimea by National Taras Shevchenko University of Kiev provides interesting data in various fields for European medieval history reseachers. Thus two reports were devoted to the studies of a medieval Italian ship that had sunk there and was excavated in 1999. Dr. Sergey Zelenko gave a speech titled "Spheroconical Vessels from a 13th-Century Ship - containers or weapons?". He concluded that the medieval ship had carried commodities in ceramic containers and a consignment of diverse glazed pottery. During the underwater excavations samples of spheroconical vessels were found and dated between the 10th and 14th century. An analysis of findings from various sites allowed historians to conclude that they were used for storage of valuable liquids which were applied in a production, medicine and cosmetics. Their military use is disputable.

The report of Ms. Katharine Valentirova was a speech titled "Cold Steel from Sunken Italian Ship of the 13th Century". The first group of weapon included the remains of daggers. Their typology corresponds to the baselard used in the Mediterranean from the 9th century. They were in continuous service with the Italian infantry until the 13th century. The second group comprised daggers and knives. She interpreted the fragments of blades without the handle as knives with oneedged blades. Further she suggested that they were multi-purpose instruments and assumed that they were the crew's personal weapons. Mr. Victor Kobets gave a speech titled "Archaeological Research of the River Dneper by the Employees of Kyiv National University in 2010-2013" and explained the use of contemporary technical equipment for underwater research.

A separate part of the conference was a seminar on the traditional Persian martial arts conducted by Dr. Manouchehr Mostagh Khorasani, a well-known historian of weapons, and the author of the most compelling up-to-date research on the history of antique weapons from Iran.

\section{3.- Conclusion}

The conference in Kyiv has demonstrated a high level of international scientific cooperation and integration for the first time in Ukraine. This event will surely set the reference bar higher for future cooperation between museums including those inside the country and overseas. The prospects of such cooperation were discussed in the report by Ms. Iryna Forostyan titled "Importance and Necessity of Collaboration between Historical Museums in the Current Geopolitical Setting". With the formation of modern civil society, the partnership and collaboration across boundaries between museums and institutions is absolutely necessary and is developing both traditionally and in a network environment. In the context of global politics, holding international joint exhibitions increase the reputation of more than one nation or culture and thus have the potential of great geopolitical importance.

Overall, the goals of the conference were reached. The conference has become a stage that marks the transition of Ukrainian weaponology and private collecting to the stage of maturity. At the same time it reflects the current status of this auxilary historical science in Ukraine with all its achievements and shortcomings. We hope this conference will become a regular event, and from now on, we will increase the quality level the help of the best national and international experts. In the near future, the organizers of the conference are planning to publish a collection of scientific papers on all topics introduced in the conference. 


\section{References}

Бієнале зброї 2014-2015. Перша міжнародна зброєзнавча конференція: тези конф., 16-19 лют. 2014 р., Київ / Міністерство оборони України, Національна академія наук України, Національний військово-історичний музей України, Інститут історії України. - К., 2014. Текст парал.: укр., рос., англ. [Weapon Biennial 2014-2015. First international research conference. Kyiv, 16-19 February 2014. Abstracts / Ministry of Defence of Ukraine, National Academy of Sciences of Ukraine, National Military Museum of Ukraine, Institute of History of Ukraine. - Kyiv, 2014].

Програма першої міжнародної зброєзнавчої конференції: програма конф., 16-19 лют. 2014 р., Київ / Міністерство оборони України, Національна академія наук України, Національний військово-історичний музей України, Інститут історії України. - К., 2014. Текст парал.: укр., рос., англ. [Program of the First international research conference. Kyiv, 16-19 February 2014 / Ministry of Defence of Ukraine, National Academy of Sciences of Ukraine, National Military Museum of Ukraine, Institute of History of Ukraine. - Kyiv, 2014].

\section{Author's biographical data}

Dr. Denis Toichkin (Ukraine) is the author of two books on the history of Cossack cold steel, 46 printed articles (including 5 encyclopedic) and has been recognized as a specialist in the late medieval and early modern history of Eastern European arms and armor. He is known as an expert in Auxiliary Historical Subjects also. The graduate of the Kiev National University (1995). Since 1998 works in the Institute of History of Ukraine, the National Academy of Sciences of Ukraine (Department of Auxilary Historical Subjects and Electronic Information Resources). The main works are: "Cossack Sabre in XVII-XVIII centuries: historical study of weapon"; "Bladed weapon of Cossack Nobles of the 16 - the first half of the 19th cc. Problems of attribution and classification”. E-mail: denisvt@yandex.ua.

Dr. Manouchehr Moshtagh Khorasani (Germany) has written five books (four related to arms and armor), co-authored one book, and 129 print articles on Persian arms and armor published in different journals across the world. His books include Persian Archery and Swordsmanship: The Historical Martial Arts of Iran, Lexicon of Arms and Armor from Iran: A Study of Symbols and Terminology (Winner of the World Book Prize of the Islamic Republic of Iran 2012), Antique Oriental and Arab Weapons and Armour: The Streshinskiy Collection, The Development of Controversies: From the Early Modern Period to Online Discussion Forums and Arms and Armor from Iran: The Bronze Age to the End of the Qajar Period (Winner of the World Book Prize of the Islamic Republic of Iran 2009). He is the founder and an active member of Razmafzar Organization dedicated to the study and academic research on historical Persian arms and armor and martial arts. E-mail: manouchehr@moshtaghkhorasani.com. 